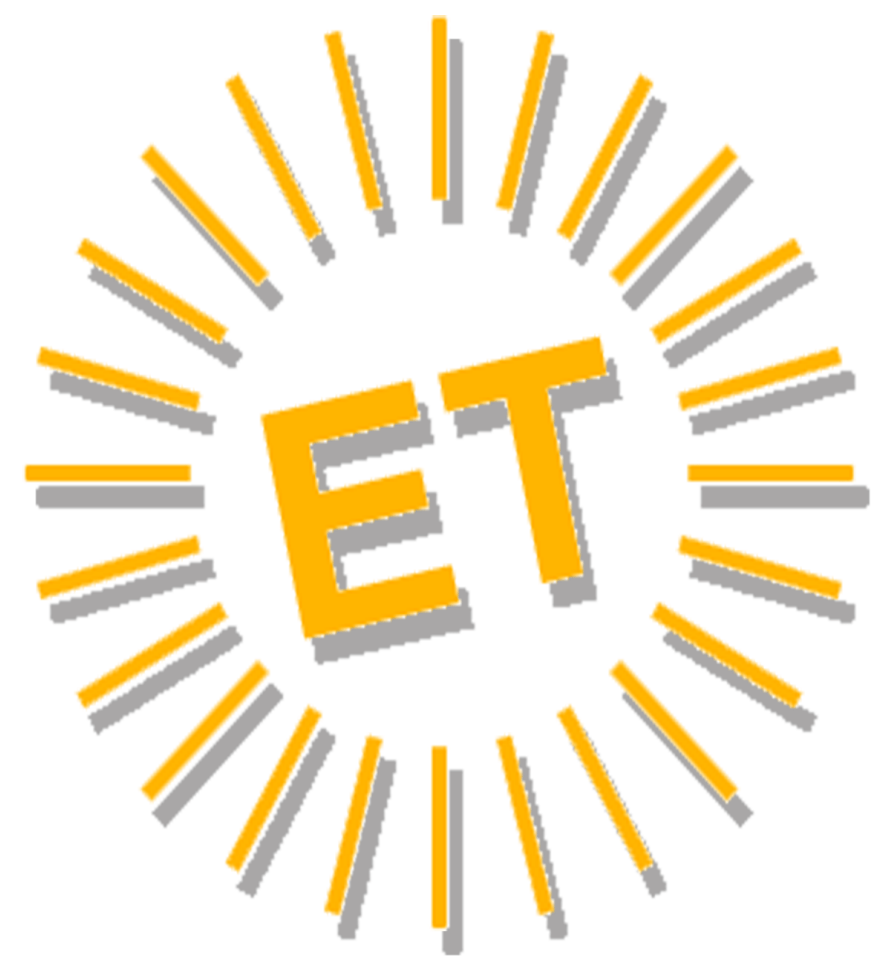




\section{Editorial Team}

\section{Editor in Chief}

Alfonso Vargas-Sánchez, University of Huelva, Spain

\section{Associate Editor}

Mirko Perano, Reald University College, Albania

\section{Books Review Editor}

Brendan Paddison, York St. John University, United Kingdom

\section{Secretariat}

Elena García de Soto, University of Huelva, Spain

Cinta Borrero-Domínguez, University of Seville, Spain

\section{Style reviewer and text editor}

Anestis Fotiadis, Zayed University, United Arab Emirates

\section{Editorial Board}

José Manuel Alcaraz, Murdoch University, Australia Mario Castellanos-Verdugo, University of Seville, Spain José Antonio Fraiz-Brea, University of Vigo, Spain José Manuel Hernández-Mogollón, University of Extremadura, Spain

Tzung-Chen Huan, National Chiayi University, Taiwan, Province of China

Shaul Krakover, Ben Gurion University, Israel Jean Pierre Levy-Mangin, University of Quebec, Canada Tomás López-Guzmán, University of Córdoba, Spain Yasuo Ohe, Chiba University, Japón

María de los Ángeles Plaza-Mejía, University of Huelva, Spain Nuria Porras-Bueno, University of Huelva, Spain João Albino Silva, Algarve University, Portugal

\section{Advisory Board (Spanish Members)}

Juan Manuel Berbel-Pineda, Pablo de Olavide University, Spain César Camisón-Zornoza, Uniersity of Valencia, Spain Enrique Claver-Cortés, University of Alicante, Spain María Teresa Fernández-Alles, University of Cádiz, Spain José Luis Galán-González, University of Seville, Spain Félix Grande-Torraleja, University of Jaén, Spain

Antonio Leal-Millán, University of Seville, Spain Inmaculada Martín-Rojo, University of Málaga, Spain Antonio Manuel Martínez-López, University of Huelva, Spain Francisco José Martínez-López, University of Huelva, Spain Pablo A. Muñoz-Gallego, University of Salamanca, Spain
Francisco Riquel-Ligero, University of Huelva, Spain José Miguel Rodríguez-Antón, Autonomous University of Madrid, Spain

Sandra Sanchez-Cañizares, University of Cordoba, Spain Josep Francesc Valls-Giménez, ESADE, Spain

\section{Advisory Board (Other European Members)}

Tindara Abbate, University of Messina, Italy Paulo Aguas, University of Algarve, Portugal Carlos Costa, Aveiro University, Portugal Dianne Dredge, Aalborg University, Denmark Salvatore Esposito de Falco, University of Rome "La Sapienza", Italy

Sheila Flanagan, Dublín Institute of Technology, Ireland Tania Gorcheva, Tsenov Academy of Economics, Bulgaria Tadeja Jere Jakulin, University of Primorska, Slovenia Metin Kozak, Mugla University, Turkey Álvaro Matias, Lusiada University, Portugal Alfonso Morvillo, National Research Council, Italy Alexandru Nedelea, Stefan cel Mare University of Suceava, Romania Claudio Nigro, University of Foggia, Italy Angelo Presenza, University "G. D'Annunzio" of Chieti-Pescara, Italy

Kanes Rajah, Royal Agricultural University, United Kingdom

\section{Advisory Board (Members from the rest of the world)}

John Allee, American University of Sharjah, United Arab Emirates

Nestor Pedro Braidot, National University of La Plata, Argentina

Roberto Elias Canese, Columbia University, Rector, Paraguay

Luca Casali, Queensland University of Technology, Australia Nimit Chowdhary, Indian Institute of Tourism and Travel Management, India

Steven Chung-chi Wu, National Pingtung University of Science and Technology, Taiwán

Dianne Dredge, Southern Cross University, Australia Daniel Fesenmaier, Temple University, United States

Babu George, Alaska Pacific University, United States Dogan Gursoy, Washington State University, United States Jafar Jafari, University of Wisconsin-Stout, United States Sanggun Lee, Pai Chai University, Korea Republic of Albert Yeh Shangpao, I-SHOU University, Taiwán Pauline Sheldon, University of Hawaii, United States Germán A. Sierra-Anaya, University of Cartagena de Indias, Rector, Colombia Xiaohua Yang, University of San Francisco, United States 
Enlightening Tourism.

A Pathmaking Journal

\title{
SOCIAL PARTICIPATION AND TOURISM PUBLIC POLICY: THE BRAZILIAN TOURISM REGIONALIZATION PROGRAM
}

\author{
Sarah Marroni Minasi \\ University of Vale do Itajaí (Brazil) \\ sarahminasi@gmail.com
}

Éverton Felipe Kaizer

Universidade Federal do Paraná (Brazil)

evertonfk@gmail.com

\author{
Rodrigo Mesquista Oliveira \\ Universidade Estadual do Rio de Janeiro (Brazil) \\ rodrigohoms@hotmail.com
}

ABSTRACT

Issues of governance, collaboration, and participation are at the forefront of much tourism public management on finding new alternatives to tourism destinations development. This paper aims to diagnose the performance of social participation in the Brazilian Tourism Regionalization Program from 2004 to 2020. This research has a qualitative approach with data collected through bibliographic and documentary research covering 2004 to 2020. The data collected were analyzed according to categories defined by the literature. We analyzed eleven Tourism Regionalization Program documents and 13 specific published articles on tourism governance instances in the Tourism Regionalization Program. As a result, we observe that social participation went from a fundamental issue in 2004 to a prerequisite for integrating a tourist region in 2020. And they are now suppressed by the targeting of protagonism for the private sector. The 
results of this research advance the theoretical discussions regarding social participation in Brazilian tourism's regionalization. The synthesis of the analyses and discussions promoted the need to rethink organizing tourism governance in the Brazilian case to meet the demand for social participation and the regional development of tourism.

KEYWORDS

Tourism Policy; Tourism Governance; Tourism Regionalization Program; Brazil

ECONLIT KEYS

R58; L83; Z32.

\section{INTRODUCTION}

As one of the possibilities to develop and diversify tourism in Brazil, the Ministry of Tourism developed the Tourism Regionalization Program (PRT) in 2004. The Program focuses on decentralizing tourism management and local empowering among the planned actions to stimulate the Brazilian tourist regions' economic and social development (Brazil, 2005; 2007a; 2011a; 2013a).

Based on the Program, cities and regions must present and implement plans for their tourism development based on society's broad participation, understanding that social participation is local empowerment. Through this, communities must participate in the decision-making process and define their needs conducting development according to regional characteristics (Hall, 2011).

Despite the advances made over the years of PRT implementation, questions remain regarding the performance for decentralizing tourism management. In terms of tourism development in the regions and in terms of implementing governance bodies. Studies show that such issues are present in the most diverse contexts (Sette, Do Vale \& Coutinho, 2014; Rodrigues \& Souza, 2015; Feger \& Veis, 2018; Alves \& Souza, 2019; Bantim \& Fratucci, 2019).

Research on PRT has progressed as results and actions began to appear. However, the availability of a critical assessment of specific aspects of governance and social participation is negligible. There is little research on the topic, and none addresses the full period of execution of the PRT (Vieira, 2011; Trentin \& Fratucci, 2011; Fernandes \& Coriolano, 2015; Pinheiro, Maracajá \& Chim-Miki, 2019; Souza-Santos \& Silva-Pereira, 2020). 
After sixteen years, has the Tourism Regionalization Program (a guideline in the National Tourism Plan) been consolidated as a significant public tourism policy for the formation of regional tourism governance in Brazil? This paper aims to diagnose the performance of social participation in the Brazilian Regionalization Program for Tourism from 2004 to 2020.

This research has a qualitative approach designed with data collected through bibliographic and documentary research. Data collection comprised publications from 2004 to 2020, the year the PRT started until the most recent year. The scientific papers' results were compared with the Ministry of Tourism's official documents regarding the Regionalization Program for Tourism. For this, the categories of analysis are a) Instance performance, b) Qualitative participation among members of the instance (Nóbrega, 2012), c) social agents' ability to articulate in a network, (d) level of managerial capacity in a region tourism (Guilarducci \& Fratucci, 2020).

The categories' choice was based on the previous reading of the articles found by the bibliographic research and the Ministry of Tourism's selected documents on the PRT. Afterward, we searched the literature for categories of analysis related to the contents covered. The research does not aim to limit the analysis to these categories but offers the perspective of analysis from them. The authors understand that other categories can also be used for other analyzes of the same content.

Discussions on public policies and tourism governance show that cases of failure implementation and effective social participation predominate. From this research, it was possible to analyze the panorama of the PRT development, especially regarding the establishment of tourism governance and social participation. This highlights the dissonance between the tourism governance guidelines proposed in the PRT and how tourism governance is organized.

\section{LITERATURE REVIEW}

The literature on the themes of tourism governance, social participation, and tourism policies points out that several tourist regions have difficulties implementing the PRT's actions. In summary, the networking of some tourist regions is deficient (Hall, 2011; Der Zee, 2017; Gullarducci \& Fratucci, 2020), there is a discontinuity of actions in the 
instances of governance due to the election of new political representatives (Gomes \& Santos, 2007; Bantim \& Fratucci, 2019). In addition, there is a lack of knowledge on tourism agents' part about governance and its benefits (Alves \& Souza, 2019).

Another point that weakens regionalization is the "push-push" of responsibilities between the governance bodies' agents (Feger \& Veis, 2018). "There must be planning and good communication between the agents involved in the implementation of the strategies and actions outlined so that the benefits are maximized, and the costs minimized" (Souza \& Morais, 2011). Integrated participation between public and private, associated entities and diversified partners can bring good results to tourism's regional governance (Hall, 2011; Rodrigues \& Souza, 2015).

Indispensable for tourism governance, social participation is essential in decisionmaking (Sá \& Brito, 2012; Conceição, 2020). However, power-sharing is incipient (Fernandes \& Coriolano, 2015), bringing inconsistencies to the completeness of participatory management (Pinheiro et al., 2019) and an environment of trust (Czernek \& Czakon, 2016; Der Zee, 2017; Nunkoo, 2017). According to Coutinho (2015, p. 133), "the distrust on the part of society, which is strategically designed to reduce its power of intervention, not engaging as it was promulgated, generating an unfavorable climate for social participation."

Despite specific public tourism policies aimed at addressing the interests of market agents (Trentin \& Fratucci, 2011), financial unsustainability is still a recurring factor in most instances of tourism governance (Sette et al., 2014; Bantim \& Fratucci, 2019; Alves \& Souza, 2019). This situation directly influences social participation, favoring tourism agents' demobilization in the involvement in regional governance (Endres \& Pakman, 2019).

It is essential to highlight the existence of other critical theoric categories to analyze the public policies. Smith (2009), for example, based his democratic goods theory inside a democratic innovation institutional environment. The author brought inclusion, popular control, judgment, and transparency to explain social participation's public policy-making performance.

\section{1) TOURISM GOVERNANCE AND SOCIAL PARTICIPATION}


Regional development becomes the main guideline for public tourism policy, leading to changes in the processes carried out in the past. Development can be understood as "a multifaceted process of intense structural transformation resulting [from] varied and complex social interactions that seek to broaden the horizon of possibilities for a given society" (Brandão, 2009, p. 154). Boisier (1996, p. 139) emphasizes that "development will result only from a dense and intelligently articulated interaction, through a collective project or a regional political project." The author also establishes six elements that influence regional development, understood as actors, institutions, culture, procedures, resources, and surroundings (Boisier, 1996). However, the mere occurrence of these elements does not determine regional development. Virtuous regional development is directly linked to how the articulation between actors, procedures, resources, institutions, surroundings, and culture will happen (Minasi, 2015). Therefore, it refers to collective skills and perspectives of the act of regionalizing.

The regionalization of tourism is a public policy model present in other countries (Herman, Grama \& Stupariu, 2016). Prokkola (2007; 2011) discussed cross-border regionalization as a cooperation project to develop tourism in northern European countries. Bulgaria adopts the regionalization model for tourism. According to Grozeva (2018), the government has adopted two types of regionalization for tourism. Greece also opted for tourism in regions still in the 1960s and 1970s (Konsolas \& Zacharatos, 1992).

Among success and failure cases, Brazil presents a public policy of regionalization different from other countries. This distinction is partly due to Brazil's continental dimensions and the administrative arrangement of the territory. In common, the management of tourism in tourist destinations is achieved through various tools to expand positive results. Tourism governance is established with this premise. For Brazilian cities regionalized and aligned with the Ministry of Tourism's tourism policy, this - tourism governance - is mandatory (Brazil, 2019a).

As a theoretical concept, it assumes that there is a demand on the part of local subjects to seek new models for collective decision-making that "improve the limitations of current decision-making processes and that also allow a more active role for different social actors" (Velasco González, 2011, p. 17). 
Fundamentally, tourism governance must involve the collaboration of the public, private, civil society, and community (Velasco González, 2014) to achieve the breadth of tourism development. Part of the concept of tourism governance in strengthening actors' participation is vulnerable to the system and the change in tourist dynamics that may generate negative repercussions (Velasco González, 2011; Lin \& Simmons, 2017; Conceição, 2020). It is critical to address in Brazil that the tourism policy formulation contemplates predominantly business associations and public sectors; thus, workers and residents have little participation in decision making (Gomes, 2018).

Social participation is one of the fundamental pillars for achieving governance. Endres and Pakman (2019) suggest that in the spaces of participation institutionalized by governance, the potential for transforming the tourism reality lies. However, to understand certain aspects of social participation in tourism governance, it is necessary to have a prior understanding of the circumstances that formalize social abstention. Conceição (2020) pointed out power relations as one of the fundamental dimensions for analyzing regional governance instances.

For Nitsche (2013), in most cases, the local community does not work with tourism projects, maintaining total dependence on public power, subject to several problems in constructing effective policies, such as public management changes. Feger \& Veis (2018, p. 113) exemplifies that the distancing of local actors in tourism projects can be caused by "[...] non-acceptance of tourism in the city or region, ignorance of the program, the depoliticization of society, aversion to the impacts of tourism, limiting the long-term vision, among others".

Or even because there is no planning capable of encompassing local interests and needs that the tourist activity would supply, indifference may materialize, and in some cases even provoke rejection on the part of local subjects (Czernek, 2013; Nitsche, 2013). Therefore, residents' need for tourism governance must be linked to improving the collaborative decision-making process with different tourism agents. In this way, to advance in the design of management policies and procedures that enable the joint development of tourism to the detriment of opportunistic behaviors and that provide measures to face the sector's problems (Gomes \& Santos, 2007; Velasco González, 2011; Pastras \& Bramwell, 2013). 


\section{2) PUBLIC POLICIES IN TOURISM}

Tourism can have desirable and undesirable effects in the territories where it develops. State intervention is essential, seeking a balance between the social, economic, and environmental aspects, premises of sustainability (Dias, 2003; Nunkoo, 2017). This intervention by the public authorities on tourism would take place through public policies.

Thus, Dias (2003, p.121) understands that "public policies are the set of actions undertaken by the State, as a subject, aimed at meeting the needs of the whole society." However, policies that are formulated and debated only by government officials are called government policies. They should not be named publicly, as they are not (Fratucci, 2009). "To become public [the policies] must be the result of a broad, open, democratic, and inclusive process that observes and respects the social practices existing in the communities where they will be implemented (Fratucci, 2009, p. 404).

Given this perspective, Ruschmann \& Solha (2014) identify that tourism policies typically present two leading positions, on the one hand, the commercial vision, seeking economic results, and on the other, using politics as a strategy for balanced development, establishing limits, and guaranteeing the needs and expectations of the natives. This last position resonates with the concept of public policy presented by Fratucci (2009), highlighting the role of the public power to work for collective interests and guide the actions of several actors (Pastras \& Bramwell, 2013) in addition to the fundamental part of public participation (Lin \& Simmons, 2017).

In the Brazilian context, the Tourism Regionalization Program (PRT) began as a public policy after creating the Ministry of Tourism in 2003 and the consequent formulation of the first National Tourism Plan (PNT), valid from 2003 until 2007. However, the understanding of tourism from the territorial context started earlier, in 1994, with creating the National Program for the Municipalization of Tourism (PNMT), aiming to boost tourism development at the municipal level (Brazil, 2013a).

In addition to other strategies, the PNMT prioritized social participation in the collective construction of municipal tourism development, awakening the integration between public, private, and local society (Brazil, 2011a). The vital collaboration of the PNMT was with the direction of tourism policy-oriented by development according to 
the territory, thus guiding the elaboration and concretization of new public tourism policy in Brazil from 2004: the Regionalization Program of Tourism - "Roteiros do Brasil". The relationship between the Regionalization Program and the National Plan for Municipalization of Tourism is well approached by Brusadin (2005), Endres (2003), and Trentin and Fratucci (2011).

The succession of public tourism policy with the practical structuring of the PRT made it clear the overcoming of obstacles identified at the local level, with the municipalities, in addition to enabling the understanding of the activity as a driver for development, from the structuring of the cities in regions, expanding the tourism production chain (Brazil, 2013b). Thus, "the launching [of the PRT] became a milestone in the National Tourism Policy: regionalization passed from planning to reality" (Brazil, 2010, p. 14).

Another important landmark is Law No. 17,771 of 2008 , which establishes the National Tourism Policy, offering subsidies and regulations, through laws and regulations, for tourism planning and ordering in Brazil (Brazil, 2008). The objectives of national policy, designated through art. 5, go through twenty items, and among these, the number six, referring to regionalization:

Promote, decentralize, and regionalize tourism, encouraging States, the Federal District, and Municipalities to plan, in their territories, tourist activities sustainably and safely, including among themselves, with the involvement and effective participation of the receiving communities in the benefits arising from the activity (Brazil, 2008, p. 01).

It showed, even more, the decentralized management of tourism in Brazil, with greater participation of the Federation Units, established in 2004, with the beginning of the Program. It stands out that the decentralization of public policies was influenced by the Constitution of the Federative Republic of Brazil of 1988, which established the social participation in public policies making for example in health (art.198), social assistance (art. 204), and culture (art. 216-A).

Currently, the PRT comprises 2,694 municipalities, divided into 333 tourist regions (Brazil, 2019c). It is worth mentioning that there is an update of the tourist regions and a new version of the Brazilian Tourism Map every two years. Besides, establishing an active municipal tourism council became mandatory for the municipality to participate in one of the 333 tourist regions validated this year by the Ministry of Tourism (Brazil, 2019b). 
Municipal councils are fundamental institutions for democratic participation. More elaborate discussions on the institutionalization of councils in public policies in Brazil were presented by Tatagiba (2002), Araújo (2011), Da Mata, Pimentel and Emmendoerfer, (2018), and Pessali and Gomes (2020).

\section{MATERIALS AND METHODS}

This is qualitative research characterized as exploratory and analytical. This study's methodological procedures are based on the relationship between governance and the regionalization of tourism in Brazil, based on data collected about the forms of social participation in the Tourism Regionalization Program. Also, it analyzes the performance of this participation over the years of execution PRT according to studies already published (Figure 1 ).

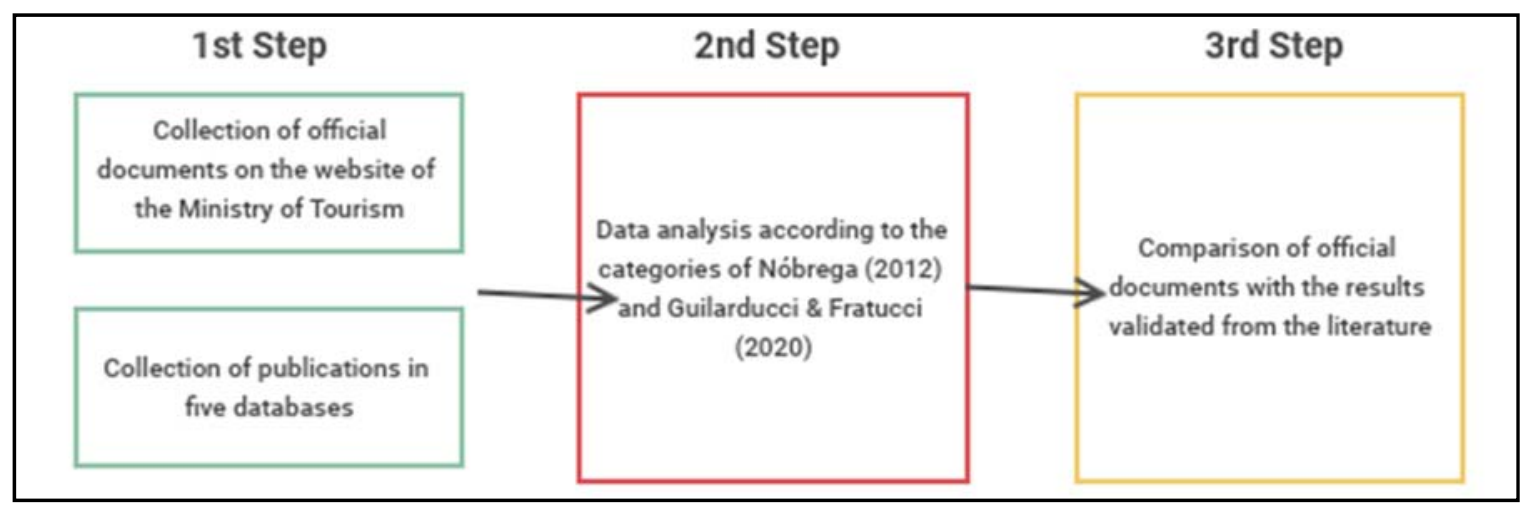

Figure 1: Methodological framework Source: Elaborated by the authors (2020).

The data for analysis were collected through bibliographic and documentary research. The bibliographic research was carried out in databases by searching for previous studies published about governance and social participation in the Tourism Regionalization Program. Together, in the documentary research, 11 official documents of the Program were consulted on the Ministry of Tourism's official website (1st Step) (Table 1). 


\begin{tabular}{|c|c|}
\hline $\begin{array}{c}\text { Módulo Operacional } 3 \\
\text { Institucionalização da Instância de Governança } \\
\text { Regional }\end{array}$ & 2005 \\
\hline $\begin{array}{c}\text { Conteúdo Fundamental } \\
\text { Ação Municipal para a Regionalização do } \\
\text { Turismo }\end{array}$ & 2007 \\
\hline $\begin{array}{c}\text { Módulo Operacional } 3 \\
\text { Institucionalização da Instância de Governança } \\
\text { Regional }\end{array}$ & $2007 b$ \\
\hline $\begin{array}{c}\text { Avaliação do Programa de Regionalização do } \\
\text { Turismo - Roteiros do Brasil }\end{array}$ & 2010 \\
\hline $\begin{array}{c}\text { Projeto "Gestão das Instâncias de Governança } \\
\text { Regionais" }\end{array}$ & 2011 \\
\hline Elaboração do Plano de Trabalho - Manual & $2011 b$ \\
\hline $\begin{array}{c}\text { Programa de Regionalização do Turismo: } \\
\text { diretrizes }\end{array}$ & $2013 a$ \\
\hline $\begin{array}{l}\text { Regionalização do Turismo: Programa Nacional } \\
\text { de Estruturação de Destinos Turísticos }\end{array}$ & $2013 b$ \\
\hline $\begin{array}{c}\text { Avaliação do Programa de Regionalização do } \\
\text { Turismo - Roteiros do Brasil }\end{array}$ & 2015 \\
\hline $\begin{array}{c}\text { Regionalização: Institucionalização da Instância } \\
\text { de Governança Regional }\end{array}$ & 2019 \\
\hline $\begin{array}{l}\text { Regionalização - Instância de Governança } \\
\text { Regional - Documento Orientador }\end{array}$ & 2019 \\
\hline
\end{tabular}

Table 1: Documents used for analysis.

Source: Elaborated by the authors (2020).

The document analysis was conducted by interpreting the theoretical concepts and by counting the incidence of keywords. The keywords were chosen based on publications content, the literature review, and the research objective. The following keywords and their derivations were: social participation (participatory, participant, participation), representation (representatives, representative, represent), society (society, civil society). After searching the documents, the number of times these words appear per year. 
In the bibliographic research, scientific articles published between 2004 (beginning of PRT) and 2020 (end of data collection) were collected in scientific journals with a double-blind review process. At the end of the survey, 15 articles were compiled and analyzed. Of these, 13 address case studies of tourist regions, and another three address PRT in general (according to Table 2 considering the categories adapted from the literature (2nd stage). The papers were results from searches in the Ebscohost, Portal de Periódicos CAPES, Publicações de Turismo, Scielo, ScienceDirect e Web of Science databases. The search criteria were the keywords: "Tourism Regionalization Program" and "Brazil." In addition, we established that the analysis only includes publications with case studies. Thus, it does not focus on any region predetermined by the authors but on the studied areas in published research.

\begin{tabular}{|c|c|c|c|}
\hline Authors & Title & Year & Location \\
\hline $\begin{array}{l}\text { Barbará, Leitão } \\
\text { \& Fontes Filho }\end{array}$ & $\begin{array}{l}\text { A governança regional em turismo: realidade? } \\
\text { Estudo de caso sobre o destino Estrada Real }\end{array}$ & 2007 & Estrada Real (MG) \\
\hline Vieira & $\begin{array}{c}\text { Planejamento e políticas públicas de turismo: } \\
\text { análise dos módulos operacionais do } \\
\text { Programa de Regionalização do Turismo no } \\
\text { Pólo São Luís - MA }\end{array}$ & 2011 & Pólo São Luís (MA) \\
\hline Fernandes & $\begin{array}{c}\text { O Programa de Regionalização do Turismo e } \\
\text { sua aplicação no circuito turístico Caminhos } \\
\text { Gerais }\end{array}$ & 2012 & Caminhos Gerais (MG) \\
\hline $\begin{array}{l}\text { Sette, do Vale } \\
\text { \& Coutinho }\end{array}$ & $\begin{array}{c}\text { O Programa de Regionalização do Turismo } \\
\text { de Minas Gerais: uma abordagem da política } \\
\text { pública estadual de turismo }\end{array}$ & 2014 & Circuitos Turísticos (MG) \\
\hline Silva \& Moesch & $\begin{array}{l}\text { Planejamento participativo e indução no } \\
\text { turismo: reflexões sobre a construção de } \\
\text { redes de cooperação na Região dos } \\
\text { Negócios, em Goiás (Brazil) }\end{array}$ & 2014 & $\begin{array}{l}\text { Região dos Negócios } \\
\qquad(\mathrm{GO})\end{array}$ \\
\hline $\begin{array}{l}\text { Fernandes \& } \\
\text { Coriolano }\end{array}$ & $\begin{array}{l}\text { A governança na política nacional de } \\
\text { regionalização do turismo: estudo dos grupos } \\
\text { gestores dos destinos indutores do Ceará }\end{array}$ & 2015 & Destinos Indutores (CE) \\
\hline $\begin{array}{l}\text { Rodrigues \& } \\
\text { Souza }\end{array}$ & $\begin{array}{l}\text { O papel da governança na regionalização do } \\
\text { turismo }\end{array}$ & 2015 & Uva e Vinho (RS) \\
\hline $\begin{array}{l}\text { Gomes, Teles } \\
\text { \& Nitsche }\end{array}$ & $\begin{array}{c}\text { Governança nas políticas públicas de turismo: } \\
\text { desafios a partir da região Rotas do Pinhão, } \\
\text { Brazil }\end{array}$ & 2016 & Rotas do Pinhão (PR) \\
\hline
\end{tabular}




\begin{tabular}{|c|c|c|c|}
\hline Feger \& Veis & $\begin{array}{c}\text { A regionalização do turismo no contexto da } \\
\text { política pública de desenvolvimento turístico } \\
\text { Brazileiro: o caso de duas regiões localizadas } \\
\text { no Estado do Paraná }\end{array}$ & 2018 & $\begin{array}{c}\text { Corredores das Águas } \\
\text { (PR) } \\
\text { Litoral do Paraná (PR) }\end{array}$ \\
\hline Alves \& Souza & $\begin{array}{c}\text { O processo de governança na Política de } \\
\text { Regionalização do Turismo de Minas Gerais: } \\
\text { uma análise do circuito turístico Caminho } \\
\text { Novo }\end{array}$ & 2019 & Caminho Novo (MG) \\
\hline $\begin{array}{c}\text { Bantim \& } \\
\text { Fratucci }\end{array}$ & $\begin{array}{c}\text { Gestão regional do turismo - participação e } \\
\text { representatividade no Conselho Regional de } \\
\text { Turismo das Agulhas Negras - RJ }\end{array}$ & 2019 & Agulhas Negras (RJ) \\
\hline $\begin{array}{c}\text { Coutinho \& } \\
\text { Azevedo }\end{array}$ & $\begin{array}{c}\text { Desenvolvimento do turismo e interface com } \\
\text { a instância de governança estadual: um } \\
\text { estudo no Rio Grande do Norte/Brazil }\end{array}$ & 2019 & Conetur (RN) \\
\hline $\begin{array}{c}\text { Pinheiro, Mara- } \\
\text { cajá \& Chim- } \\
\text { Miki }\end{array}$ & $\begin{array}{c}\text { Política pública de regionalização do turismo: } \\
\text { um estudo sobre a participação social no polo } \\
\text { de turismo Seridó }\end{array}$ & 2019 & Pólo Seridó (RN) \\
\hline $\begin{array}{c}\text { Souza-Santos } \\
\text { \& Silva-Pereira }\end{array}$ & $\begin{array}{c}\text { O turismo como impulsionador do } \\
\text { desenvolvimento regional: análise no Campo } \\
\text { das Vertentes (MG), Brazil }\end{array}$ & 2020 & Campo das Vertentes \\
(MG)
\end{tabular}

Table 2: Study cases used for analysis.

Source: Elaborated by the authors (2020).

The established categories were: A) Performance of the Instances, B) Qualitative participation among the members of the instance (Nóbrega, 2012), C) Capacity of social agents to articulate in a network, and D) Level of the managerial capacity of a tourist region (Guilarducci \& Fratucci, 2020). In category A) Instance Performance adapted from Nóbrega (2012), the relationship between the discourse plan and the effectiveness of the actions was considered. Category B) Qualitative participation among members of the instance of governance (Nóbrega, 2012) highlights society's representation as a whole and the autonomy of this participation. Category C) Capacity of social agents to articulate in Guillarducci and Fratucci (2020) network deals with communicating public power, private initiative, and civil society. Finally, D) Level of managerial capacity in a tourist region (Guilarducci \& Fratucci, 2020) refers to the perception of management developed in the tourist region.

The results found in the literature were analyzed in parallel with the contents of the official documents (3rd Step). We combined qualitative approaches to discuss and analyze data crossing the documents and publications' content. 


\section{FINDINGS}

\section{1) WHAT THE OFFICIAL DOCUMENTS TELL US ABOUT GOVERNANCE IN TOURISM AND SOCIAL PARTICIPATION?}

The Ministry of Tourism documents is a reference for the PRT and provided the content to identify what in theory was thought for the Program regarding governance in tourism and social participation. Thus, it was first analyzed how the Ministry of Tourism determines these concepts and what social participation means to tourism management.

According to the National Tourism Regionalization Program's base document, developed by the Ministry of Tourism (2013a), participation was one of the main strategies in designing the Tourism Regionalization Program. The execution of a national program with 27 Federation Units would necessarily include decentralization and sharing responsibilities. Therefore, the guidelines that guide the PRT, according to the Ministry of Tourism (2013b, p. 07), are:

I. Territorial approach;

II. Social Integration and Participation;

III. Inclusion;

IV. Decentralization;

V. Sustainability;

VI. Innovation;

VII. Competitiveness.

The tourism management model is based on the idea of shared management, which is evidenced in the document "Regionalization of Tourism: National Program for Structuring Tourist Destinations," citing that "[...] participation, democratization, consensus and agreements, involving multiplicity and diversity of institutional entities, economic agents and organized civil society" (Brazil, 2013b, p. 25). In this sense, it highlights that decision-making must be carried out together. 
According to the PRT (Brazil, 2019a, p. 12), the term governance refers to the "act of governing, conducting, governing, and harmoniously integrating the different interests, policies, and perspectives of regional development [...]". The formalization of governance must occur through institutionalizing a Regional Governance Instance (IGR). They have the role of articulating "[...] public, private, social and third sector actors whose objective is to propose, analyze, coordinate and monitor policies, plans, projects and actions in the pursuit of sustainable tourism development [...] "(Brazil, 2019b, p. 11) Therefore," [...] institutionalization is the formal establishment of policies and actions [...] through the governance structure whose objective will be to develop and implement plans, programs and projects aimed at regional tourism (Brazil, 2019b, p. 11).

The institutionalization process of an IGR must follow three main steps for its consolidation (Figure 2).

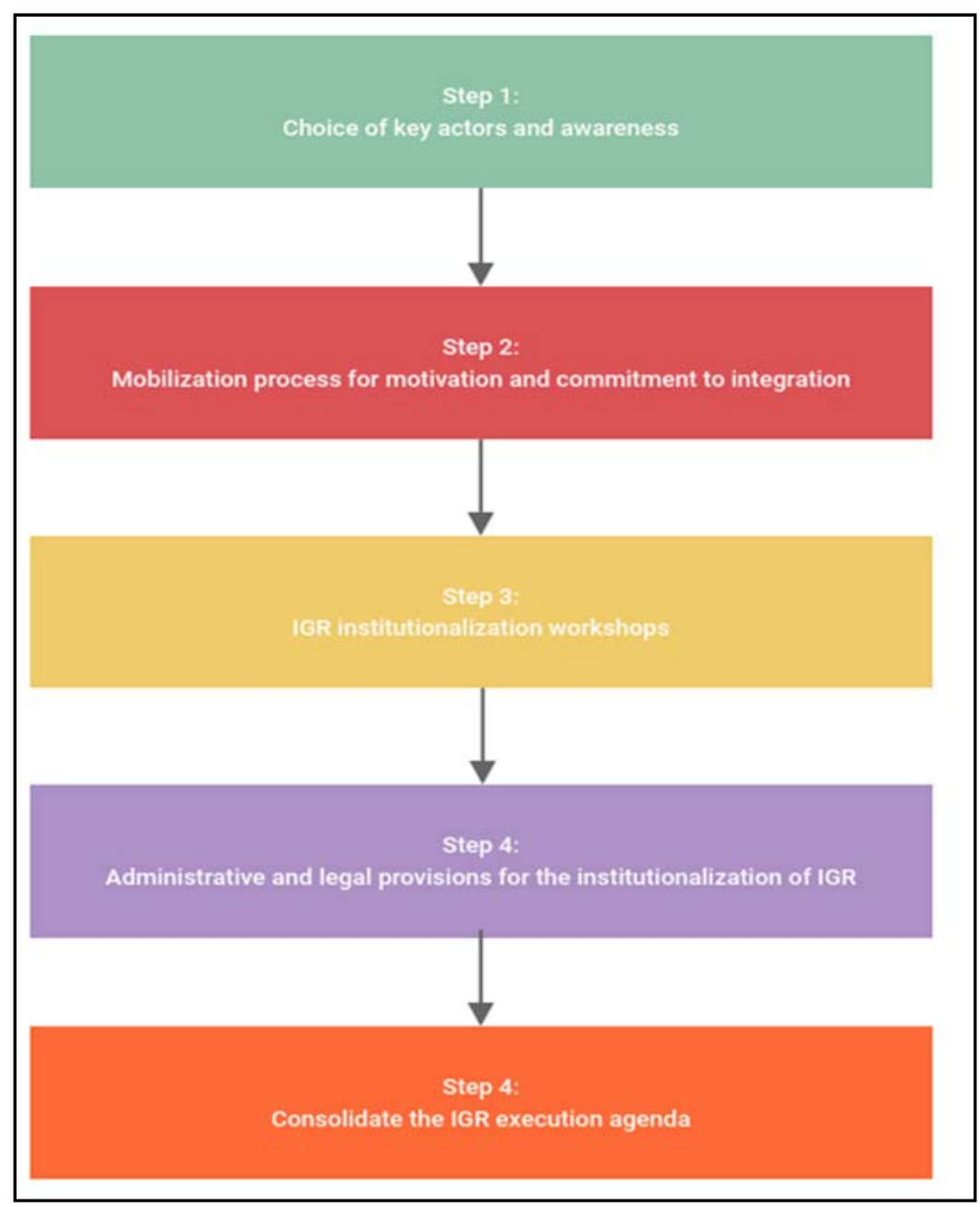

Figure 2: Steps for the institutionalization of IGRs.

Source: Adapted from Institucionalização da Instância de Governança Regional - Documento Orientador (2019b). 244 
The first StepStep should be to identify and raise awareness of potential actors or leaders articulated with local and regional tourism development, presenting the proposal, and inviting them to discuss the possible institutionalization of an IGR (Step 1) (Brazil, 2019b).

Next, the mobilization will help in the process of responsibility, integration into the process, and execution of decisions taken collectively (Brazil, 2019b) (Step 2). The training of the selected actors, on the other hand, aims to make evident the actions of an IGR, the individual and collective responsibilities of the participants, in addition to the objectives, competencies, strategies, and challenges of regional tourism development (Brazil, 2019b) (Step 3). Finally, the final steps refer to legal aspects for the formalization and organization of IGRs (Step 4 and Step 5).

The selection of members should be made through a parity composition, considering that the votes of the public, private, and community sectors have the same weight in the decision-making process (Brazil, 2005), an aspect reiterated in the update of the document in 2007 (Brazil, 2007a). Currently, editing the document suggests that the private sector will gradually take over the majority and the leadership in the development process of the IGRs (Brazil, 2019a).

Thus, shared management is structured at the national, state, regional, and city levels subdivided into two groups: institutional actors, responsible for discussing and deliberating federal, state, regional, and municipal demands. Operational actors have the mission of supporting the PRT's implementation and monitoring its execution (Brazil, 2013a).

The first group members are the Councils, Forums, Instances, Official tourism agencies, and the Ministry of Tourism. On the other hand, the second covers state, regional and municipal interlocutors, with their specific duties for each spatial area. They work mainly to strengthen and extend the PRT mobilization network (Brazil, 2013a).

According to the Ministry of Tourism (2013b), "being a decentralized, coordinated and integrated public policy management model, its structure encompasses all institutional and political spheres up to the desired social reach, that is, the community." However, the PRT evaluation document (2010, p. 45) shows that decentralization oc- 
curred in a heterogeneous way, "involving the public sector more than the private sector [...]". It was reported that six years of PRT implementation were insufficient to alter Brazil's political and administrative culture, advocated by the public sector's sole responsibility about tourism development in the country (Brazil, 2010).

Such weaknesses, also concerning public-private cooperation, would be better articulated with the existence of action planning. To build a strategic tourism plan, since "only $40 \%$ of priority regions have "a strategic tourism plan (Brazil, 2010, p. 47).

According to the Ministry of Tourism (Brazil, 2013b, p. 04), there have been advances in the implementation of PRT, as an example, "[...] the strengthening of shared management, the focus on the market, the diversification and expansion of the offer tourism, initiatives to support routing, the valorization of production associated with tourism and the process of building public policies in a participatory manner". However, the difficulties encountered in tourist macro-regions are similar. According to the PRT evaluation document, such as, "the discontinuity of managers and leaders, scarcity of financial resources, little involvement of the private sector, disarticulation between the actions and areas of the MTur and loss of focus of the program from the creation of 65 inducing destinations" (PRT, 2010, p. 45). 


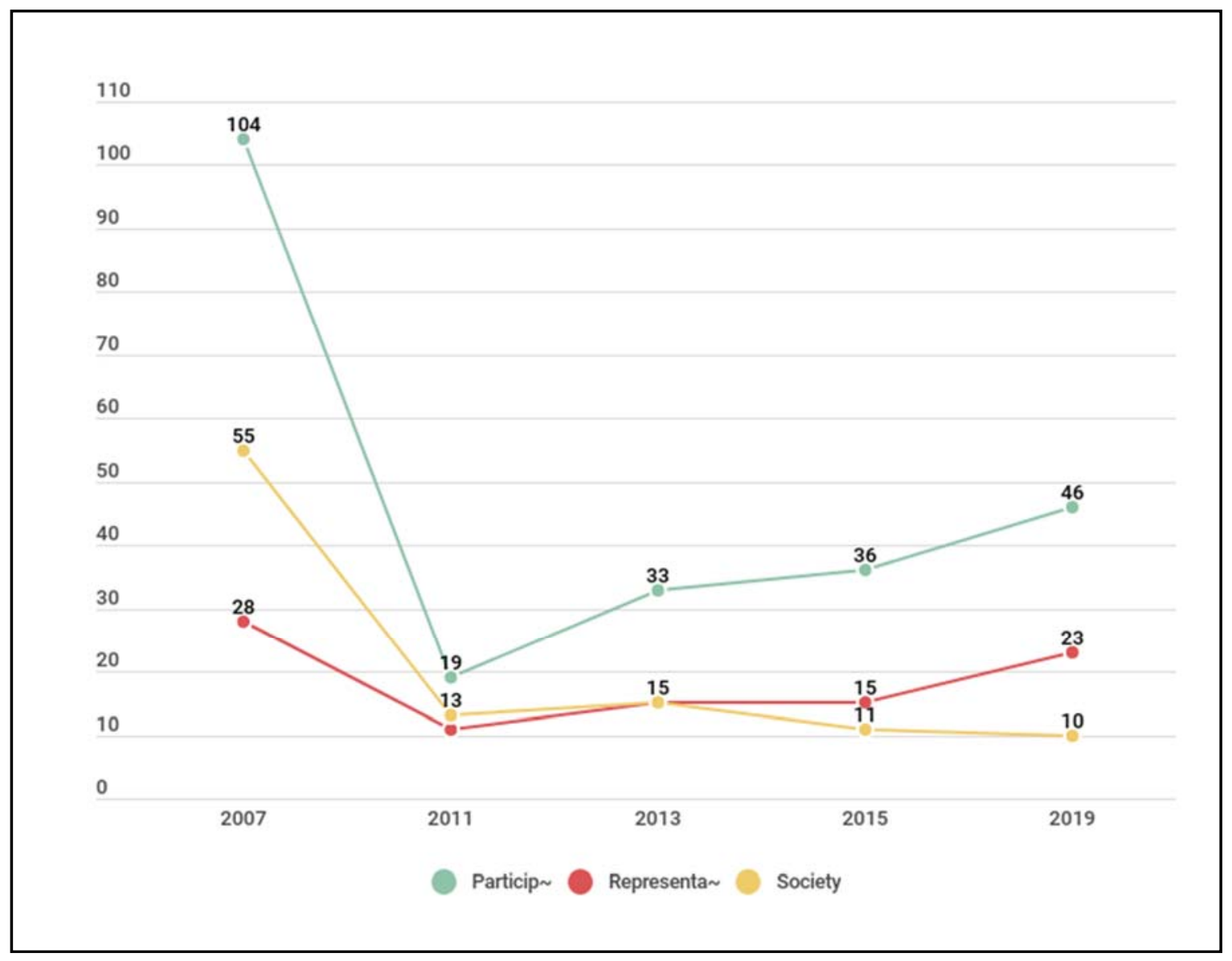

Figure 3: Incidence of keywords in PRT documents.

Source: Elaborated by the authors (2020).

The documents' temporal analysis shows the positioning of MTur and changes in the theoretical conception of the PRT. From selecting keywords on the topics of interest, it is possible to overview these changes. The PRT design document in 2007 is the one that concentrates more repetitions of the terms participation, society, and representativeness (and their derivatives). Although the documents written in 2011 show an improvement in the number of repetitions, it does not represent half of the pioneer documents' incidence. It is worth noting the term "society" was the one that showed the most significant drop over the years.

By observing the behavior of keywords in the documents, it is possible to draw a parallel to PRT development since its beginning. On the one hand, the decrease in the frequency of keywords can be associated with overcoming these issues. On the other hand, it shows a change in the direction of the initial proposals prepared by the MTur. 
At the same time, it shows that changes in the federal administration also influenced the premises.

\section{2) REGIONAL TOURISM GOVERNANCE IN BRAZIL}

The documents govern tourism policies and seek to guide the paths that can be taken to realize tourism development in Brazil. However, this effectiveness will depend on the practice, initiative, action, interaction, and coordination of the different tourism agents. It is this aspect that will be analyzed in this section.

Category A: Regional tourism development

For a governance body to have a compelling performance, Nóbrega (2012) considers the regularity of meetings with guidelines aiming at tourism development and the execution of the group's actions to be essential. Thus, it is worth noting that the time is taken to carry out activities and public-private partnerships with diversified associations and partners in the long term generate the consolidation of the work carried out to develop regional tourism within a governance instance (Rodrigues \& Souza, 2015).

In the tourist region Campo das Vertentes (MG), for the construction of policies aimed at regional development, the governance body seeks to systematize interests, articulate and establish priorities, and mediate political differences rooted in the region (Souza-Santos \& Silva-Pereira, 2020).

Despite the advances made in the governance of tourism in the State of Ceará (CE), the inducing destinations' management groups understand that for governance effectiveness. It is necessary to support the structuring processes and greater involvement and commitment of the public power with the IGRs' deliberations (Fernandes \& Coriolano, 2015).

There are also difficulties for the performance of the instances, such as lack of communication between the tourist regions and the state public power, as in the case of Minas Gerais (Sette et al., 2014), and discontinuity of actions in the municipalities that compose the regional tourism council of Agulhas Negras (RJ), due to the frequency of 
the election of new political representatives (Bantim \& Fratucci, 2019). The same situation can be found in Rotas do Pinhão (PR), in which planning and actions are not continued due to changes in political-party management (Gomes, Teles \& Nitsche, 2016).

In the case of Estrada Real (MG), four years after IGR, Barbará, Leitão and Fontes Filho (2007) point out the need for more excellent articulation, communication, and integration between public, private, and community to a democratic governance model, seen that these issues are fundamental to regional development.

\section{Category B: Quality of social participation}

As for this category, Nóbrega (2012) understands how the representatives participate in IGR discussions, also considering their frequency. Along with understanding and believing in the necessary condition of joint participation in the group, all components remain informed.

The Pólo de Turismo Seridó (RN) is organized as a tourism council, including several sectors of society: public, private, educational institutions, and organized civil society. However, it needs other social actors to integrate participatory tourism management (Pinheiro et al., 2019). In the Conetur of Rio Grande do Norte (RN), social agents' participation is prevented by the rules and procedures established by the council itself. So, there is no equal decision-making. Also, there is a concentration of guidelines on tourism in the capital and encouraging the overvaluation of a single tourist segment in the State (Coutinho \& Azevedo, 2019).

Qualitative participation in the Agulhas Negras region (RJ) comprises members who do not have the power to make decisions or do not participate fully in them (Bantim \& Fratucci, 2019). In Ceará (CE), the management groups were set up in an articulated manner to decentralize the power-sharing among the different members. However, in practice, these actions are not carried out (Fernandes \& Coriolano, 2015).

Silva and Moesch (2014) observe the low representativeness of cities surrounding Goiânia in the governance Region of Business (GO). Participants are demobilized because of the repetition of agendas (discussions in the scope of the City Tourism Council of Goiânia also become an agenda for IGR meetings). The insistence on repeated 
agendas makes the neighboring cities from the state capital not feel represented in that environment (Silva \& Moesch, 2014).

In society's current economic situation, market interests end up overlapping other claims and consensus of public policies. This issue reflects other members' qualitative participation, making them play a secondary role in decision-making (Trentin \& Fratucci, 2011). In short, the purpose of managing regional territories with the broad participation of multiple agents becomes challenging to achieve in practice (Bantim \& Fratucci, 2019).

\section{Category C: Capacity to work collectively}

Guilarducci and Fratucci (2020) understand that social agents' ability to articulate occurs due to their behavior within the regional network and their articulation level. Besides, difficulties in the political, financial, and structural spheres can weaken regional tourism development, in this case, as observed in the São Luís Pole (MA) by Vieira (2011).

It is observed in the tourist region Caminho Novo (MG) that cooperation for regional development was compromised due to the lack of representation and engagement of tourist agents in the municipalities that make up the IGR (Alves \& Souza, 2019). Furthermore, the instance members do not understand the role of governance and its benefits (Alves and Souza, 2019). As also seen from the study by Silva and Moesch (2014) in the Business Region (GO). There is a deficit in understanding the regional forum members of what it would be like to act and work together in a regionalized way.

This issue is also reported by Fernandes (2012) in the tourist circuit Caminhos Gerais (MG) since representatives of the tourist region have difficulties understanding what regionalization is and what it is. The inefficient network articulation capacity interferes with the application of PRT taking into account that there are political barriers in the state and the municipalities (Fernandes, 2012). Another critical factor is the lack of confidence in the cities that make up the instance. In addition to the reduced habit of taking collective actions, which interferes in the cooperation between regionalized municipalities and, consequently, in the regional tourism development, in this case, in the Rotas do Pinhão region (PR), as pondered by Gomes et al., (2016). 
Category D: Planning and management of regional governance

On a regional scale, the responsibility for carrying out tourism management is based on the IGRs (Guilarducci \& Fratucci, 2020). Thus, there are diverse interests within the IGRs, making it difficult to reach consensus, as observed in Agulhas Negras (RJ) in Bantim and Fratucci (2019) research. Governments such as Caminho Novo (MG) and Agulhas Negras (RJ) face the obstacle of financial unsustainability in the management of regional tourism, leading to incomplete actions at the region, weakening tourism development (Alves \& Souza, 2019; Sette et al., 2014; Bantim \& Fratucci, 2019). Many regional governance actions are not previously planned, making them reactive rather than idealized proposals (Feger \& Veis, 2018).

The centrality of planning and actions aimed at the public sector makes it difficult to carry out projects due to financial insufficiency, as seen by Gomes et al., (2016) when carrying out their study at Rotas do Pinhão (PR). Furthermore, in Caminhos Gerais (MG), it is understood that the state understands regionalization aimed at routing, and the objective of the PRT is broader and includes other spheres of tourism development. In addition to prioritizing resources, already consolidated tourist region, failing to invest resources in others that need structuring (Fernandes, 2012).

\section{ANALYSIS AND DISCUSSIONS}

It can be seen, with the results presented in the previous chapter, that the barriers to regional tourism development are very close to each other. We observed common challenges, which consider the different scenarios and local realities and permeate a good portion of the cases exposed in this study.

When we focus on the processes of regionalization of tourism, it is evident that the regional exercise of tourism is based mainly on cooperation, further, in collaboration between different parties. This principle guides other interests linked to tourism agents and municipalities, leading them to a fundamental consensus on tourism management.

However, in many cases, the members, and sometimes even the federative entity, tourism governance, do not even understand the central Brazilian public tourism policy. 
That is the guide to cities towards regionalization. This lack of knowledge reflects the difficulty of working cooperatively. Regionalization policy, work, and regional development are not understood. These are assumptions contrary to the collective process, which is the regional development indicated by Boisier (1996), Brandão (2009), and Minasi (2015). Much less, the meaning and importance of the existence of an IGR, an essential tool for tourism management, is understood.

It is not uncommon for times when tourism governance is seen as an opportunity to obtain privileged information from a member (including to become an individual and competitive market differential). Such behavior acts by preventing the exercise of the collective capacity for articulation and collaboration in tourist governance instances (Velasco González, 2014).

Concerning the composition of the governances, the document dealing with the institutionalization of IGRs in the year 2019 suggests a selection of members "with an emphasis on the private sector, guiding so that it can take over the process gradually" (Brazil, 2019a). However, this recommendation has been remodeled over the years, because in 2005, the document that directs the institutionalization of IGRs guides that in the "decision-making processes, the public, private and third sectors act in a standing position. equality and that the vote has the same value in decision making" (Brazil, 2005).

As of the 2019 document, it has been recommended that the private sector coordinate IGRs and that these secret agents have more excellent representation among members. The consequences of this new recommendation can influence residents' active participation and decrease the public interest in acting as a mediator or coordinator. An opposite result to the aims attributed to the governance bodies, which in their design offer guarantees for the diversity of discussion and participation in the regional tourism development process.

\section{CONCLUSIONS}

Based on the findings, we sought to monitor how the state's political action is being put into practice in Brazilian tourist regions, grounded on the analysis intended in this study. Tourism managers and those responsible for tourism in regionalized cities (or 
not) may use this study as a tool for the constant development of political action at the local and regional levels.

The paper diagnosed concerning cases from previous studies that the ways of social participation changed over the years. By comparing the documents from the Tourism Regionalization Program and previous research about the different forms of social participation in this public policy, we observe that social participation went from a fundamental issue in 2004 to a prerequisite for integrating a tourist region in 2020 . And they are now suppressed by the targeting of protagonism for the private sector.

It appears that the formulation and orientation of regionalization policies for tourism alone are not helpful for its completeness and effectiveness, which involves integration, participation, collaboration, understanding, implementation, and other factors. It is essential to make the training process of the members of Regional Governance Instances a continuous exercise of informing and training, this being the responsibility of the public authorities.

It is understood that the current recommendation on the composition of members of the IGRs may reduce the coordination and mediation of the public authorities and discourage the participation of different social agents since decision-making would mainly concentrate on private agents. Thus, the guidelines and interests of a group would be privileged if compared to the others.

With the occurrences of COVID-19, tourism was strongly impacted, and the Brazilian tourist regions felt the losses equally (Paraná, 2021). These factors highlighted the importance of the state and the integrated and participatory tourism planning for the recovery of Brazil's sector.

Based on the results achieved in this study, we sought to contribute to a theoretical analysis at a macro level on Brazilian regional development with various case studies, differently from what had been occurring in the literature, which allowed us to identify, at times, similar problems in different local contexts. The findings seek to promote an orientation towards the changes of scenery required in the area. At the same time, it indicates that there are still fundamental issues that need to overcome regional and decentralized tourism management in Brazil. 
As limitations of this study, it is necessary to highlight the use of data from previous research. For further investigation, the recommendation is to understand how the future of social participation in post-pandemic tourism governance instances of COVID19 will be, considering the changes in tourism activity and especially the economic and social repercussions in the places. Furthermore, it would be interesting to analyze Brazilian tourism's regional governance social participation starting from the set of attributes proposed by Smith (2009), using other lenses to observe the research object of this study.

\section{References}

Alves, M.B.; Souza, T.F.C. O processo de governança na política de Regionalização do Turismo de Minas Gerais: uma análise do Circuito Turístico Caminho Novo. Revista Acadêmica Observatório de Inovação do Turismo, Vol. 13, No 3, 2019, pp. 46-69.

Araújo, C.M. Gestão pública democrática e democracia participativa no Brasil: Disseminação dos conselhos de políticas públicas, no âmbito do turismo, no Estado de São Paulo. Tourism \& Management Studies, Vol. 1, 2011, pp. 396-406.

Bantim, N.; Fratucci, A. Gestão regional do turismo-participação e representatividade no Conselho Regional de Turismo das Agulhas Negras-RJ. Revista Brasileira de Pesquisa em Turismo, Vol. 13, No 1, 2019, pp. 108-124.

Barbará, S.; Leitão, M.C.D.S.; Fontes Filho, J.R. A governança regional em turismo: realidade? Estudo de caso sobre o destino Estrada Real. Cadernos EBAPE, Vol. 5, No 4, 2007, pp. 1-16.

Boisier, S. Em busca do esquivo desenvolvimento regional: entre a caixa-preta e o projeto político. Planejamento e políticas públicas, No 13, 1996, pp. 111-143.

Brandão, C. Desenvolvimento, territórios e escalas espaciais: levar na devida conta as contribuições da economia política e da geografia crítica para construir a 
abordagem interdisciplinar. In Ribeiro, M.T.F.; Milani, C.R.S. Compreendendo a complexidade socioespacial contemporânea: o território como categoria de diálogo interdisciplinar. Salvador: EDUFBA, 2009, pp. 150-185.

Brazil. Módulo Operacional 3 - Institucionalização da Instância de Governança Regional, 2005. Retrieved from

http://regionalizacao.turismo.gov.br/images/roteiros brasil/institucionalizacao da ins tancia de governanca regional.pdf [accessed 20 September 2020].

Brazil. Conteúdo Fundamental - Ação Municipal para a Regionalização do Turismo, 2007a. Retrieved from

https://www.terrabrasilis.org.br/ecotecadigital/index.php/estantes/uso-publicoecoturismo/221-roteiros-do-brasil-conteudo-fundamental-acao-municipal-para-aregionalizacao-do-turismo [accessed 11 August 2020].

Brazil. Módulo Operacional 03 - Institucionalização da Instância de Governança Regional, 2007b. Retrieved from

https://www.terrabrasilis.org.br/ecotecadigital/index.php/estantes/uso-publicoecoturismo/193-roteiros-do-brasil-modulo-operacional-03-institucionalizacao-dainstancia-de-governanca-regional [accessed 20 September 2020].

Brazil. Law No 11.771. Dispõe sobre a Política Nacional de Turismo. Brasília, DF, 2008. Retrieved from

http://www.planalto.gov.br/ccivil 03/ ato2007-2010/2008/lei//11771.htm [accessed 20 September 2020].

Brazil. Avaliação do Programa de Regionalização do Turismo - Roteiros do Brasil, 2010. Retrieved from

http://www.turismo.gov.br/sites/default/turismo/o ministerio/publicacoes/downloads publicacoes/Livro Regionalizaxo.pdf [accessed 20 September 2020]. 
Brazil. Projeto “Gestão das Instâncias de Governança Regionais”, 2011a. Retrieved from

http://regionalizacao.turismo.gov.br/images/roteiros brasil/institucionalizacao da ins tancia de governanca regional.pdf [accessed 20 September 2020].

Brazil. Elaboração do Plano de Trabalho - Manual, 2011b. Retrieved from http://regionalizacao.turismo.gov.br/images/Manual\%20PT\%20\%20Mar\%C3\%A70\%20de\%202020m.pdf [accessed 20 September 2020].

Brazil. Programa de Regionalização do Turismo - Diretrizes, 2013a. Retrieved from http://regionalizacao.turismo.gov.br/images/pdf/PROGRAMA DE REGIONALIZACA O DO TURISMO - DIRETRIZES.pdf [cited 20 September 2020].

Brazil. Regionalização do Turismo: Programa Nacional de Estruturação de Destinos Turísticos, 2013b. Retrieved from

https://www.cnm.org.br/cms/images/stories/Links/08052013 Programa de Regionali zao Turismo.pdf [accessed 20 September 2020].

Brazil. Avaliação do Programa de Regionalização do Turismo - Roteiros do Brazil, 2015. Retrieved from

http://www.turismo.gov.br/sites/default/turismo/o ministerio/publicacoes/downloads publicacoes/Livro Regionalizaxo.pdf [accessed 20 September 2020].

Brazil. Regionalização - Instância de Governança Regional - Documento Orientador, 2019a. Retrieved from

http://regionalizacao.turismo.gov.br/images/conteudo/Cartilha\%204 \%2020pgs Instit ucionalizacao\%20da\%20Estancia final2.pdf [accessed 20 September 2020].

Brazil. Regionalização: Institucionalização da Instância de Governança Regional, 2019b. Retrieved from

http://www.regionalizacao.turismo.gov.br/images/mtur-cartilha-promocional-mod2A\%20-\%20Inst.\%20da\%20IGR\%20Final.pdf [accessed 20 September 2020]. 
Brazil. Mapa do Turismo 2019-2021, 2019c. Retrieved from http://www.mapa.turismo.gov.br/mapa/init.html\#/home [accessed 20 September 2020].

Brusadin, L.B. Estudo da avaliação do Programa Nacional de Municipalização do Turismo - PNMT na gestão do presidente Fernando Henrique Cardoso. Revista Hospitalidade, No 2, 2005, pp. 87-112.

Conceição, C.C. Modelo analítico de governança regional de turismo-MAGRET. Revista Brasileira de Pesquisa em Turismo, No 2, 2020, pp. 123-138.

Coutinho, A.C.A. Políticas públicas, desenvolvimento local e participação social nas instâncias de governança associadas ao turismo no Rio Grande do Norte. Masters Thesis, Universidade Federal do Rio Grande do Norte, Natal, Rio Grande do Norte, Brazil, 2015.

Coutinho, A.C.A.; Azevedo, F.F. Desenvolvimento do Turismo e a Interface com a Instância De Governança estadual: Um estudo no Rio Grande do Norte/Brasil. PASOS Revista de Turismo y Patrimonio Cultural, Vol. 17, No 4, 2019, pp. 655-669.

Czernek, K.; Czakon, W. Trust-Building Processes in Tourist Coopetition: The Case of a Polish Region. Tourism Management, Vol. 52, No February, 2016, pp. 380-394.

Czernek, K. Determinants of cooperation in a tourist region. Annals of Tourism Research, Vol. 40, No January, 2013, pp. 83-104.

Da Mata, G.M.F.; Pimentel, T.D.; Emmendoerfer, M.L. Teoria do Campo Social e Políticas Públicas: O Caso do Conselho Gestor de Turismo de Juiz de Fora, MG, Brasil. Rosa Dos Ventos - Turismo e Hospitalidade, Vol. 10, No 2, 2018, pp. 332-354. 
Der Zee, E.V. Complexity in the governance of tourism networks: balancing between external pressure and internal expectations. Journal of Destination Marketing \& Management, Vol. 6, No 4, 2017, pp. 296-308.

Dias, R. Planejamento do Turismo: política e desenvolvimento do turismo no Brasil. São Paulo: Atlas, 2003.

Endres, A.V. Redes Políticas como Novo Instrumento de Condução Política do Estado: Contextualização Frente à Complexidade Social e Possibilidades para o Planejamento Turístico. Turismo: Visão e Ação, Vol. 5, No 3, 2003, pp. 217-238.

Endres, A.V.; Pakman, E.T. A governança das políticas de turismo: o papel dos espaços de participação na perspectiva da análise de redes e da teoria institucional. Revista Brasileira de Pesquisa em Turismo, Vol. 13, No 1, 2019, pp. 1-18.

Feger, J.E.; Veis, E.L. A regionalização do turismo no contexto da política pública de desenvolvimento turístico Brasileiro: O caso de duas regiões localizadas no Estado do Paraná. CULTUR: Revista de Cultura e Turismo, Vol. 12, No 1, 2018, pp. 95-117.

Fernandes, F.L. O programa de regionalização do turismo e sua aplicação no circuito turístico caminhos gerais. Revista Gestão \& Conhecimento, Edição Especial, 2012, pp. 463-478.

Fernandes, L.M.M.; Coriolano, L.N.M.T. A governança na política nacional de regionalização do turismo: estudo dos grupos gestores dos destinos indutores do Ceará. Turismo: Visão e Ação, Vol. 17, No 2 , 2015, pp. 247-278.

Fratucci, A. Refletindo sobre a gestão dos espaços turísticos: perspectivas para as redes regionais de turismo. Turismo em Análise, Vol 10, No 3, 2009, pp. 391-408.

Gomes, B.M.A. Políticas Públicas de Turismo e os Empresários. São Paulo: All Print, 2018. 
Gomes, B.M.A.; Santos, A.C. Influências das políticas públicas de Turismo nas transações entre os agentes: uma análise sob a ótica da ECT. Revista Brasileira de Pesquisa em Turismo, Vol. 1, No 2, 2007, pp. 72-100.

Gomes, B.M.A.; Teles, M.A.; Nitsche, L.B. Governança nas políticas públicas de turismo: desafios a partir da região Rotas do Pinhão, Brasil. Revista Espacios, Vol. 37, No 16, 2016, p. 14.

Grozeva, M. Overview and analysis of the main tourist regionalizations of Bulgaria. Proceedings of the International scientific and practical conference "Bulgaria of regions", No 1, 2018, pp. 105-116. Retrieved from http://science.uard.bg/index.php/regions/issue/view/31_[accessed 20 September 2020].

Guilarducci, B.C.; Fratucci, A.C. Análise da rede social da Instância de Governança do Circuito Turístico Caminho Novo, MG: uma perspectiva sistêmica e complexa. Revista Brasileira de Pesquisa em Turismo, Vol. 14, No 1, 2020, pp. 140-160.

Hall, C.M. A typology of governance and its implications for tourism policy analysis. Journal of Sustainable Tourism, Vol. 19, No 4-5, 2011, pp. 437-457.

Herman, G.V.; Grama, V.; Stupariu, I.M. The international organisation between globalization and regionalization. Case study: World Tourism Organization. Revista Română de Geografie Politică, Vol. 28, No 2, 2016, pp. 49-59.

Konsolas, N.; Zacharatos, G. Regionalization of Tourism Activity in Greece Problems and Policies. In Briassoulis, H.; Straaten, J. V.D Tourism and the Environment, Dordrecht: Springer, 1992, pp. 319-329. 
Lin, D.; Simmons, D. Structured inter-network collaboration: Public participation in tourism planning in Southern China. Tourism Management, Vol 63, No December, 2017, pp. 315-328.

Minasi, S. Planejamento do turismo na perspectiva territorial na região extremo sul do RS/Brasil. Revista de Turismo Contemporâneo, Vol 3, No 1, 2015, pp. 138-165.

Nitsche, L.B. Por um turismo para as comunidades locais. Revista Turismo e Sociedade. Vol 6, No 3, 2013, pp. 713-717.

Nóbrega, W.R. de M. Turismo e políticas públicas na Amazônia Brasileira: instâncias de governança e desenvolvimento nos municípios de Santarém e Belterra - Oeste do Pará. Doctoral Thesis, Universidade Federal do Pará. Belém, Pará, Brazil, 2012.

Nunkoo, R. Governance and sustainable tourism: What is the role of trust, power, and social capital? Journal of Destination Marketing \& Management, Vol. 6, No 4, 2017, pp. 277-285.

Paraná. Coronavírus. Retomada do turismo no PR, 2021. Retrieved from http://www.turismo.pr.gov.br/Coronavirus [accessed 16 March 2021].

Pastras, P.; Bramwell, B. A strategic-relational approach to tourism policy. Annals of Tourism Research. Vol. 43, No October, 2013, pp. 390-414.

Pessali, H.F.; Gomes, B.M.A. Instituições de democracia participativa: bens democráticos nos conselhos de políticas públicas de Curitiba. Curitiba: PUCPRESS, 2020.

Pinheiro, I.D.F.; Maracajá, K.F.; Chim-Miki, A. Política pública de regionalização do turismo: um estudo sobre a participação social no polo de turismo Seridó. Turismo: Visão e Ação, Vol 22, No 1, 2020, pp. 162-184. 
Prokkola, E. Cross-border Regionalization and Tourism Development at the SwedishFinnish Border: "Destination Arctic Circle". Scandinavian Journal of Hospitality and Tourism, Vol 7, No 2, 2007, pp. 120-138.

Prokkola, E. Regionalization, Tourism Development, and Partnership: The European Union's North Calotte Sub-programme of INTERREG III A North. Tourism Geographies, Vol 13, No 4, 2011, pp. 507-530.

Rodrigues, S.D.L.; Souza, M.D. O papel da Governança na regionalização do turismo. Revista Brasileira de Ecoturismo, Vol. 8, No 2, 2015, pp. 234-250.

Ruschmann, D.V.M.; Solha, K. Planejamento turístico. São Paulo: Manole, 2014.

Sá, H.D.S.F.; Brito, C.M. O sentido da participação da comunidade local no planejamento e desenvolvimento do turismo. Proceedings of Festival de Turismo do $\begin{array}{lllll}\text { Iguassu, } & \text { No } & \text { 2012. } & \text { Retrieved from }\end{array}$ https://www.anaisforumturismoiguassu.com.br/2012/07/anais-2012.html_[accessed 20 September 2020].

Sette, I.R.; do Valle, M.I.M.; Coutinho, M.P.C. O Programa de Regionalização do Turismo de Minas Gerais: uma abordagem da política pública estadual de turismo. Revista Turismo em Análise, No 3, 2014, pp. 608-627.

Silva, P.T.; Moesch, M.M. Planejamento participativo e indução no turismo: reflexões sobre a construção de redes de cooperação na 'Região dos Negócios' em Goiás (Brasil). Revista Turismo \& Desenvolvimento, No 21, 2014, pp. 329-337.

Smith, G. Democratic Innovations. Cambridge: Cambridge University Press, 2009.

Sousa-Santos, T.D.; Silva-Pereira, R.D. O turismo como impulsionador do desenvolvimento regional: análise no Campo das Vertentes (MG), Brasil. EURE (Santiago), No 137, 2020, pp. 113-133. 
Souza, R.O.; Morais, J.M.L. Políticas Públicas para o Turismo: Uma forma de incrementar o Desenvolvimento Econômico e Social de uma região. Cadernos de Cultura e Ciência, No 2, 2011, pp. 83-94.

Tatagiba, L. Os conselhos gestores e a democratização das políticas públicas no Brasil. In Dagnino, E. Sociedade civil e espaços públicos no Brasil. São Paulo: Paz e Terra, 2002.

Trentin, F.; Fratucci, A.C. Política Nacional de Turismo no Brazil: da municipalização à regionalização. Tourism \& Management Studies, No 1, 2011, pp. 839-848.

Velasco González, M. La política turística: una arena de acción autónoma. Cuadernos de turismo, No 27, 2011, pp. 953-969.

Velasco González, M. Gobernanza turística: ¿Políticas públicas inovadoras o retórica banal?. Caderno Virtual de Turismo, No 1, 2014, pp. 9-22.

Vieira, A.R.M. Planejamento e Políticas Públicas de Turismo: análise dos módulos operacionais do Programa de Regionalização do Turismo no Polo São LuísMA. MastersThesis, Universidade de Brasília, Brasília, Distrito Federal, Brazil, 2011.

Article info: Received 08/01/2021. Accepted 16/04/2021. Refereed anonymously. 